\title{
Fluorescent oligonucleotide rDNA probes that specifically bind to a common nanoflagellate, Paraphysomonas vestita
}

\author{
Jason Rice, ${ }^{1,2}$ C. David O'Connor, ${ }^{2}$ Michael A. Sleigh, ${ }^{1}$ Peter H. Burkill, ${ }^{3}$ \\ Ian G. Giles ${ }^{2}$ and Mikhail V. Zubkov'
}

\author{
Author for correspondence: Michael A. Sleigh. Tel: +44 1703 594425. Fax: +44 1703594269. \\ e-mail: sleigh@soton.ac.uk
}
1,2 Departments of Biology 1 and Biochemistry², School of Biological Sciences, University of Southampton, Bassett Crescent East, Southampton S016 7PX UK
3 Plymouth Marine Laboratory, Prospect Place, Plymouth PL1 3DH, UK

\begin{abstract}
Nanoflagellates are ecologically important, but morphological identification requires techniques which are not practicable for use in quantitative studies of populations; alternative methods of accurate recognition of nanoflagellate species in mixed populations are therefore desirable. Fluorescent oligonucleotide probes which hybridize with unique sequences of the small subunit (SSU) rRNA have been exploited as 'phylogenetic stains' in the identification of bacteria. In this paper we describe the preparation and application of probes which specifically hybridize with a common nanoflagellate species, Paraphysomonas vestita. The sequence of nucleotides in the SSU rRNA gene of this flagellate was determined and compared with those of related species to select unique $P$. vestita sequences 18-21 nucleotides in length. Five sequences in different parts of the SSU rRNA gene were used to design 5'-fluorescently labelled oligonucleotide probes. Published sequences were used to make probes that hybridized with all eukaryotes (EUK) or any cellular organism (UNI), and probes were designed not to hybridize with rRNA (CON). Optimum conditions for hybridization were determined. In all cases, UNI probes hybridized with the cells, but CON probes were only bound to a limited extent. All five probes targeted to $P$. vestita proved to be species-specific; they hybridized well with this species, but not with three other species of the same genus, nor with three more distantly related flagellate species, nor with a ciliate, nor with bacteria. These probes provide a means of quantitatively measuring the proportion of $P$. vestita cells in samples of mixed protists.
\end{abstract}

Keywords: fluorescent oligonucleotide probes, flagellate recognition, ribosomal RNA, nanoflagellates

\section{INTRODUCTION}

Heterotrophic nanoflagellates are the principal consumers of bacterial production in all aquatic habitats and in soils (Azam et al., 1983; Fenchel, 1982; Clarholm, 1984), and there is a need to understand better their role in microbial food webs (Fenchel, 1988; Sherr \& Sherr, 1994). These nanoflagellates are very small, commonly

Abbreviations: FITC, fluorescein isothiocyanate; SSU, small subunit; $T_{m}$ melting temperature; TRITC, tetramethylrhodamine isothiocyanate.

The EMBL accession numbers for the rRNA nucleotide sequences of Paraphysomonas vestita, Paraphysomonas foraminifera, Paraphysomonas butcheri and Paraphysomonas imperforata determined in this paper are Z28335, Z38025, Z29679 and Z29680, respectively. between 3 and $10 \mu \mathrm{m}$ in diameter, and, although characteristics of their motility can often permit identification of individual live cells, distortions which occur during fixation usually make identification by light microscopy impossible. Consequently, the identification of nanoflagellate species often depends on features which can be discriminated only by electron microscopy. If quantitative ecological studies require electron microscopy for identification of the organisms present, the number of samples and number of individuals studied are necessarily restricted because of the time and expense involved, and such studies also run the risk of loss of or damage to the fragile cells. We have therefore sought alternative methods of identification which do not depend on examination of the structural features of every specimen. 
Two accurate molecular recognition methods have been developed which can be used to characterize microorganisms in mixtures. Fluorescent antibodies to specific epitopes present on or in microbial cells have been used to detect specific cells (Bohlool \& Schmidt, 1980; Campbell et al., 1994), but have limitations related to both the production of antisera to raise antibodies and the reliability of the presence of the epitope in all cells at all stages of the life of the organism. More recently, the potential of using oligonucleotide probes complementary to specific regions of rRNA, usually the small subunit (SSU) 16-18S rRNA, has been exploited to identify specific categories of prokaryotic and eukaryotic micro-organisms (Göbel et al., 1987; Giovannoni et al., 1988; Stahl et al., 1988; DeLong et al., 1989; Stahl \& Amann, 1991; Amann et al., 1995). Since rRNA is present in large copy numbers in cells at all stages of their life, an oligonucleotide complementary to a portion of the SSU rRNA sequence has many potential targets in every cell. Probes with many different levels of specificity can be designed (Amann et al., 1990, 1992; Devereux et al., 1992; Hicks et al., 1992), and can be labelled with radioisotopes (Giovannoni et al., 1988) or with fluorochromes to make 'phylogenetic stains' (DeLong et al., 1989). Fluorescent oligonucleotide probes are small (usually about 20 nucleotides in length), entering suitably fixed cells easily compared with fluorescent antibodies, and have an excellent range of predictable specificities; oligonucleotide probes are therefore preferred to antibodies for use in identification of microorganisms.

Ecological studies of bacteria have benefited from the use of such probes. Probe analysis of natural populations reveals the presence of many bacteria which have not been grown in culture, including new species (Giovannoni et al., 1990; Ward et al., 1990; Olsen, 1994); numbers based on plate counts are thus inaccurate underestimates. Bacteria in drinking water (Manz et al., 1993) and picoplanktonic Archaea (DeLong et al., 1994) have been identified using rRNA probes. So far, only broad spectrum eukaryote-specific probes have been used in ecological studies on flagellate and ciliate protozoa (Lim et al., 1993, 1996).

This paper reports on the development of fluorescent oligonucleotide probes which specifically target a very common nanoflagellate, Paraphysomonas vestita and describes tests to optimize their use. These probes impart a strong fluorescence to specific flagellates, which may be enumerated easily in mixed populations. Comparative measurements of the intensity of fluorescence of individual stained cells by fluorescence microscopy (e.g. Lee \& Kemp, 1994) can also permit quantitative physiological studies on the cells of known species of flagellate in the presence of other organisms.

\section{METHODS}

Cultures. Four species of the colourless chrysophyte flagellate genus Paraphysomonas were isolated by serial dilution from a plankton sample from Southampton Water by Dr S. M. Tong. These species were $P$. butcheri, $P$. foraminifera, $P$. imperforata and $P$. vestita; they were distinguished from one another by the fine structure of the scales borne by these cells (Fig. 1). Stock cultures were maintained in filtered $(0.2 \mu \mathrm{m})$ artificial sea water (containing $423 \mathrm{mM} \mathrm{NaCl}, 25.5 \mathrm{mM} \mathrm{MgSO}_{4} .7 \mathrm{H}_{2} \mathrm{O}$, $22 \cdot 9 \mathrm{mM} \mathrm{MgCl} .6 \mathrm{H}_{2} \mathrm{O}, 9 \cdot 27 \mathrm{mM} \mathrm{CaCl} .6 \mathrm{H}_{2} \mathrm{O}, 9 \mathrm{mM} \mathrm{KCl}$ and $2.15 \mathrm{mM} \mathrm{NaHCO}_{3}$ ) in tissue culture flasks. These cultures were incubated in the dark at $10^{\circ} \mathrm{C}$ and a suspension of Vibrio natriegens was added every 2 weeks as a food source. Working cultures of the flagellates containing $5 \times 10^{4}-1 \times 10^{5}$ cells ml $^{-1}$ were grown in the dark at $17^{\circ} \mathrm{C}$ in sterile 1 litre flasks containing $500 \mathrm{ml}$ sterile artificial sea water enriched with $0.05 \%$ yeast extract (Oxoid) and inoculated with $V$. natriegens. Stock cultures of $V$. natriegens were maintained on $5.5 \%\left(\mathrm{w} / \mathrm{v}\right.$ ) marine agar (Difco) plates at $10^{\circ} \mathrm{C}$, and subcultured monthly. Flagellates of the four species of Paraphysomonas were used in both the design and the testing of hybridization of probes. In addition, the following flagellates, maintained in culture in the same way as Paraphysomonas spp., were used to test the rDNA probes: Pteridomonas danica, Cafeteria roenbergensis and Bodo saliens isolated from Southampton Water by Dr S. M. Tong, and the ciliate Uronema marinum isolated from the Solent (a channel which connects Southampton Water to the open sea) by Dr M. V. Zubkov.

Design and production of probes. Species-specific oligonucleotide probes to SSU rRNA were designed to hybridize only with the rRNA of $P$. vestita. To identify suitable unique target sequences of about 15-20 nucleotides in the SSU rRNA of $P$. vestita, direct $P C R$ amplification and direct sequencing of the SSU rRNA gene were performed.

Cultures of $P$. vestita were concentrated by centrifugation at $1000 \mathrm{~g}$ and then resuspended in phosphate buffered saline (PBS) containing $137 \mathrm{mM} \mathrm{NaCl}, 2.7 \mathrm{mM} \mathrm{KCl}, 1.5 \mathrm{mM}$ $\mathrm{KH}_{2} \mathrm{PO}_{4}$ and $15 \mathrm{mM} \mathrm{Na} \mathrm{HPO}_{4}(\mathrm{pH} 7 \cdot 2$ ), at a cell concentration of $10^{5}-10^{6} \mathrm{ml}^{-1}$ in a volume of $100 \mu \mathrm{l}$. After lysis of the cells with $0.5 \%$ SDS, the solution was extracted three times with phenol and the DNA it contained purified further on a DNA clean-up column (Promega). The SSU rRNA genes in this purified DNA were amplified by PCR over 30 cycles using Taq polymerase with primers designed to anneal to conserved regions near each end of the SSU rRNA gene (Neefs et al., 1990, 1991). The sequences of these primers, given the numbers 3, 3C, 4, 4C, 5 and 6 are listed in Table 1. The amplified DNA was isolated by electrophoresis on an $0.8 \%$ agarose gel and further purified with a Geneclean II kit (Bio101) and a Magic DNA clean-up column (Promega). The full length of the SSU rRNA gene of $P$. foraminifer $a$ and the V4 regions (see below) of the SSU rRNA genes of P. butcheri and $P$. imperforata were also amplified in this way.

The purified PCR products were sequenced using the CircumVent thermal cycle sequencing kit (New England Biolabs). The primers used to amplify the full-length genes were used to commence sequencing from either end of the genes, and additional primers (numbered 7 to 18 in Table 1) were designed from the sequences as they were determined. The use of multiple primers gave an assurance of complete unambiguous sequences between the original primers because overlapping sequences of nucleotides were determined, and both strands of the template DNA were sequenced. To sequence the V4 regions of $P$. butcheri and $P$. imperforata, only primers 11 and 16 were used.

The flagellate cultures also contained the bacterial food organism $V$. natriegens, which could conceivably contain genes that would hybridize with the primers selected to amplify the Paraphysomonas genes. Genomic DNA from $V$. natriegens was isolated, purified and subjected to PCR using 

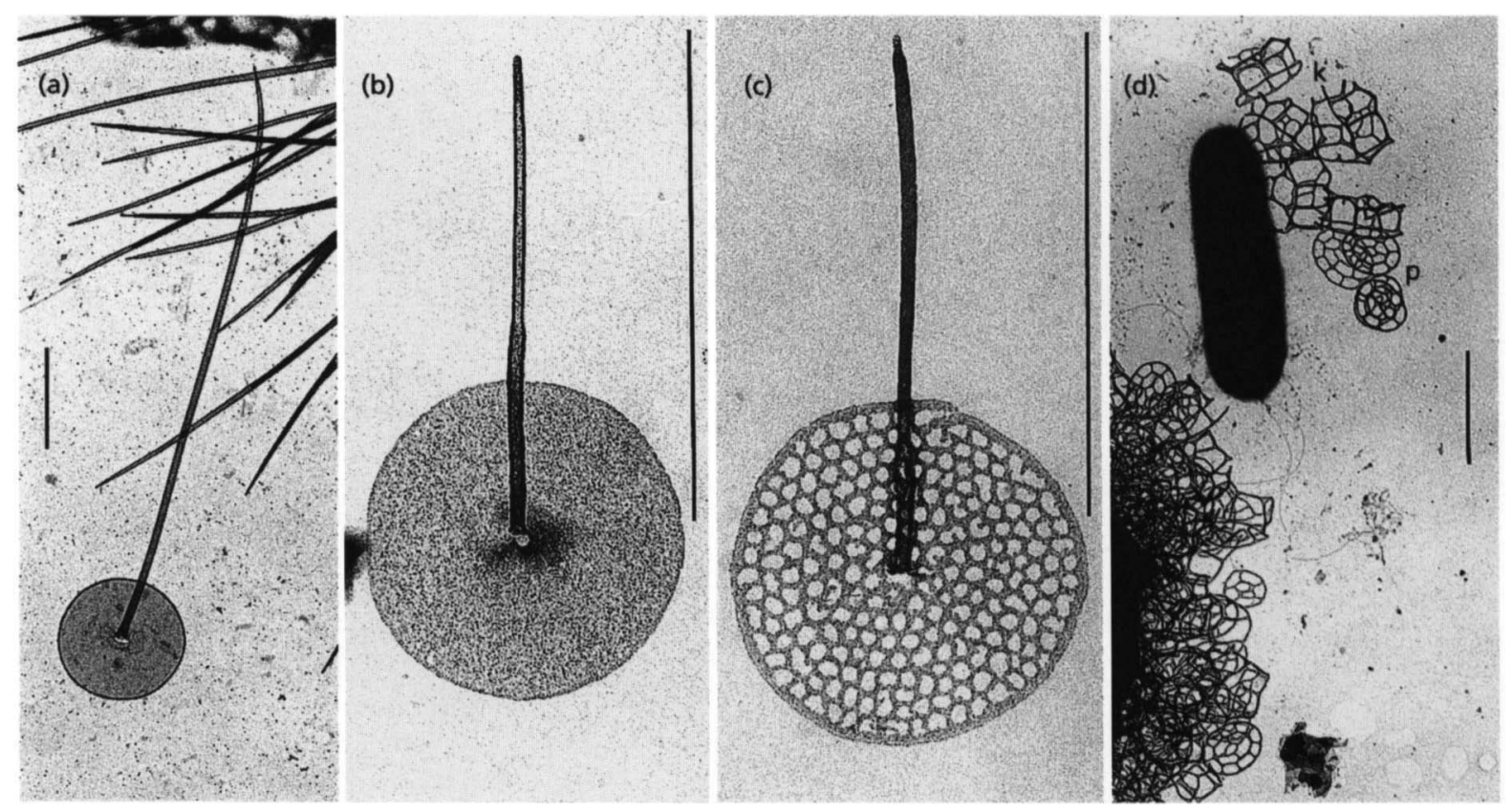

Fig. 1. Electron micrographs showing cell body scales which are diagnostic of the four species of Paraphysomonas that were used in this study. (a) P. vestita, (b) P. imperforata, (c) P. foraminifera, (d) P. butcheri. The plate scales ( $p$ ) and the crown scales $(k)$ of $P$. butcheri are quite unlike the spine scales of the other three species. Bars, $1 \mu \mathrm{m}$.

the primers which were used for $P$. vestita. However, no products were detected by electrophoresis.

The SSU rRNA gene sequences were then aligned with those of ten closely related organisms in the EMBL database, using CLUSTAL w (version 1.4) (Thompson et al., 1994). Sequences of the following species were used (with EMBL accession numbers in parentheses): Achlya bisexualis (M32705), Bacillaria paxillifer (M87325), Cylindrotheca closterium (M87326), Hibberdia magna (M87331), Lagenidium giganteum (X54266), Mallomonas papillosa (M55285), Mallomonas striata (M87333), Nannochloropsis salina (M87328), Ochromonas danica (M32704) and Synura spinosa (M87336). Alignment of the sequences permitted the identification of regions of sequence unique to $P$. vestita. Such candidate sequences were screened to select those with the most appropriate characteristics in terms of complementarity and melting temperature $\left(T_{\mathrm{m}} ; \sim 60^{\circ} \mathrm{C}\right.$ for hybridizations at approx. $45^{\circ} \mathrm{C}$ ).

Five sequences from the SSU rRNA gene of $P$. vestita were thus selected as probes (PV1 to PV5). These were synthesized (Genosys Biotechnologies) and labelled with either a tetramethylrhodamine isothiocyanate (TRITC) or a fluorescein isothiocyanate (FITC) moiety at the $5^{\prime}$ end of the oligonucleotide. The following labelled comparator probes were also synthesized commercially: general eukaryote probe EUK 1209R (EUK); universal probes UNIVERSAL A (UNIA) and UNIVERSAL C (UNIC); two control probes, CON1 and CON2, with sequences identical to unique regions of the $P$. vestita SSU rRNA, and which therefore should not bind to it; and two probes PI1 and PI2, designed to bind to the V4 region of $P$. imperforata, which served as additional controls (see Table 1 for the sequences of all probes used).

Probe hybridization. A range of methods were tested to optimize conditions for flagellate fixation and probe hybridization. These methodological variations are indicated here, and the conclusions about optimal conditions that were determined are described in Results.

Cultured nanoflagellates or $V$. natriegens were concentrated by centrifugation at 1000 and $1500 \mathrm{~g}$, respectively, and

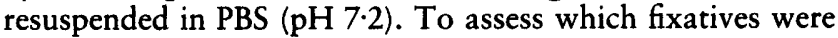
most suitable, separate batches of the cells were fixed by addition of each of the following (final concentrations): $1 \%$ acetic acid; $0.5-3.7 \%$ formaldehyde; $0.5 \%$ glutaraldehyde; 1 vol. saturated mercuric chloride: 10 vols culture; or $0.2-1 \%$ TCA, and held at $4{ }^{\circ} \mathrm{C}$ overnight. Cells were pelleted again and after being resuspended in $2 \mathrm{ml} 95 \%$ ethanol they could be stored at $-20^{\circ} \mathrm{C}$ for at least 6 months without reduction in the efficiency of hybridization. Some fixatives caused cell lysis, the extent of which was determined by comparison of cell counts (made using a haemocytometer) before and after fixation; the standard deviation of cell counts was $10-20 \%$ of the mean count. Fixation also caused changes in cell size which were determined by microscopic measurement of cell diameter using an ocular micrometer on samples of at least 25 cells subjected to each treatment; the standard deviation of the diameter measurements was always $10-20 \%$ of the mean value.

For tests on hybridization efficiency by fluorescence microscopy, flagellates or bacteria were normally attached to gelatin-coated slides, prepared following the method described by Lee $e t$ al. (1993). Ten to thirty microlitres of the fixed cell suspension was spotted onto a gelatin-coated slide and spread with the pipette to form a smear about $1 \mathrm{~cm}$ in diameter. After the slide had been air-dried for at least $1 \mathrm{~h}$ at room temperature, $10 \mu \mathrm{l}$ of a hybridization mixture containing $50 \mathrm{ng}$ of the oligonucleotide probe in a hybridization buffer $[0.2 \%$ bovine serum albumin, $0 \cdot 1 \%$ SDS and $5 \times$ SET buffer (750 mM NaCl, 5 mM Na ${ }_{2}$ EDTA, $100 \mathrm{mM}$ Tris, pH 7.8)] was spread over the cell smear. The slide was placed in a prewarmed airtight chamber containing a tissue soaked in $5 \times$ 
Table. 1. Nucleotide sequences of oligonucleotide probes and primers used in this study

Degenerate nucleotide residue codes used here are $K=T$ or $G, M=A$ or $C, R=A$ or $G, W=T$ or $A$, and $Y=T$ or $C$. The sequences for UNIA and EUK (as EUK 1209R) are derived from Giovannoni et al. (1988), and that for UNIC from Lee et al. (1993) (after removal of a $G$ residue from the $3^{\prime}$ end).

\begin{tabular}{|c|c|c|c|}
\hline Oligonucleotide & Nucleotide sequence ( $5^{\prime}$ to $3^{\prime}$ ) & $\begin{array}{c}T_{\mathbf{m}} \\
\left({ }^{\circ} \mathrm{C}\right)^{*}\end{array}$ & Remarks \\
\hline PV1 & TAAAACCCATCCTATTATATC & $60 \cdot 3$ & $\begin{array}{l}P . v e s t i t a \text {-specific probe, complementary to } \\
\text { residues } 618-638 \text { of rRNA sequence }\end{array}$ \\
\hline PV2 & TTCCGTATGCCAGTCAGA & $65 \cdot 9$ & $\begin{array}{l}\text { P. vestita-specific probe, complementary to } \\
\text { residues } 157-174 \text { of rRNA sequence }\end{array}$ \\
\hline PV3 & AGTATAAATATCACAGTCCGA & $60 \cdot 6$ & $\begin{array}{l}P . \nu e s t i t a \text {-specific probe, complementary to } \\
\text { residues } 1679-1699 \text { of rRNA sequence }\end{array}$ \\
\hline PV4 & ATATAATCTTTTCGATGATGA & $60 \cdot 8$ & $\begin{array}{l}\text { P. vestita-specific probe, complementary to } \\
\text { residues } 676-696 \text { of rRNA sequence }\end{array}$ \\
\hline PV5 & СССАТССТАТTATATCAGAAA & $63 \cdot 0$ & $\begin{array}{l}P \text {. vestita-specific probe, complementary to } \\
\text { residues } 613-633 \text { of rRNA sequence }\end{array}$ \\
\hline PI1 & GGACCGGTCGCCACG & $72 \cdot 5$ & $\begin{array}{l}\text { P. imperforata-specific probe, complementary } \\
\text { to a section of the V4 region of its rRNA } \\
\text { sequence }\end{array}$ \\
\hline P12 & AACTGAATGCCAGACGC & $64 \cdot 2$ & $\begin{array}{l}\text { P. imperforata-specific probe, complementary } \\
\text { to a section of the V4 region of its rRNA } \\
\text { sequence }\end{array}$ \\
\hline CON1 & GAGCCTGAGAAACGGC & $64 \cdot 6$ & $\begin{array}{l}\text { Control probe, corresponds to residues } 366-381 \\
\text { of } P \text {. vestita rRNA sequence }\end{array}$ \\
\hline CON2 & GTAATTCCAGCTCCAAT & $57 \cdot 8$ & $\begin{array}{l}\text { Control probe, corresponds to residues } 553-569 \\
\text { of } P \text {. vestita } \text { rRNA sequence }\end{array}$ \\
\hline UNIA & GWATTACCGCGGCKGCTG & $73 \cdot 7$ & $\begin{array}{l}\text { Universal probe, complementary to residues } \\
542-559 \text { of } P \text {. vestita rRNA sequence }\end{array}$ \\
\hline UNIC & ACGGGCGGTGTGTACAA & $69 \cdot 2$ & $\begin{array}{l}\text { Universal probe, complementary to residues } \\
1629-1645 \text { of } P \text {. vestita rRNA sequence }\end{array}$ \\
\hline EUK & GGGCATCACAGACCTG & $62 \cdot 1$ & $\begin{array}{l}\text { Eukaryote-specific probe, complementary to } \\
\text { residues } 1422-1437 \text { of } P \text {. vestita rRNA } \\
\text { sequence }\end{array}$ \\
\hline 3 & TCTAAGGGCATCACAGACCTG & $71 \cdot 9$ & $\begin{array}{l}\text { Sequencing primer complementary to residues } \\
1422-1442 \text { of } P \text {. vestita rRNA sequence }\end{array}$ \\
\hline $3 \mathrm{C}$ & CAGGTCTGTGATGCCCTTAGA & $71 \cdot 9$ & $\begin{array}{l}\text { Sequencing primer corresponding to residues } \\
1422-1442 \text { of } P \text {. vestita } \text { rRNA sequence }\end{array}$ \\
\hline 4 & AAGGAMGGCAGCAGGCGCGYAAAT & $85 \cdot 1$ & $\begin{array}{l}\text { Sequencing primer corresponding to residues } \\
392-415 \text { of } P \text {. vestita } \text { rRNA sequence }\end{array}$ \\
\hline $4 \mathrm{C}$ & ATTTRCGCGCCTGCTGCCKTCCTT & $86 \cdot 8$ & $\begin{array}{l}\text { Sequencing primer complementary to residues } \\
392-415 \text { of } P \text {. vestita } \text { rRNA sequence }\end{array}$ \\
\hline 5 & TGATCCTTCYGCAGGTTCAC & $69 \cdot 8$ & $\begin{array}{l}\text { Sequencing primer designed to match highly } \\
\text { conserved } 5^{\prime} \text { end of rRNA sequences }\end{array}$ \\
\hline 6 & ACCTGGTTGATCCTGCCAGTAG & 74.9 & $\begin{array}{l}\text { Sequencing primer designed to match highly } \\
\text { conserved } 3^{\prime} \text { end of rRNA sequences }\end{array}$ \\
\hline 7 & TTTCCCGTGTTGAGTC & $59 \cdot 6$ & $\begin{array}{l}\text { Sequencing primer complementary to residues } \\
1179-1194 \text { of } P \text {. vestita rRNA sequence }\end{array}$ \\
\hline 9 & CCCTAACACGATACAC & $53 \cdot 1$ & $\begin{array}{l}\text { Sequencing primer complementary to residues } \\
1529-1544 \text { of } P \text {. vestita rRNA sequence }\end{array}$ \\
\hline 10 & TGCCAGTCAGAGTTTT & $56 \cdot 2$ & $\begin{array}{l}\text { Sequencing primer complementary to residues } \\
152-167 \text { of } P \text {. vestita } \text { rRNA sequence }\end{array}$ \\
\hline 11 & TTTCGCAGTTGTTCGTCT & $66 \cdot 0$ & $\begin{array}{l}\text { Sequencing primer complementary to residues } \\
917-934 \text { of } P \text {. vestita } \text { rRNA sequence }\end{array}$ \\
\hline 12 & CCTGGTTTTTTATTGGTGATT & $68 \cdot 3$ & $\begin{array}{l}\text { Sequencing primer corresponding to residues } \\
212-232 \text { of } P \text {. vestita } \text { rRNA sequence }\end{array}$ \\
\hline 13 & ATCTTTTCGATGATGATATG & $61 \cdot 5$ & $\begin{array}{l}\text { Sequencing primer complementary to residues } \\
672-691 \text { of } P \text {. vestita } \text { rRNA sequence }\end{array}$ \\
\hline
\end{tabular}


Table. 1 (cont.)

\begin{tabular}{|c|c|c|c|}
\hline Oligonucleotide & Nucleotide sequence $\left(5^{\prime}\right.$ to $\left.3^{\prime}\right)$ & $\begin{array}{c}T_{m} \\
\left({ }^{\circ} \mathbf{C}\right)^{*}\end{array}$ & Remarks \\
\hline 14 & GCTTTGGATGGTAGGGTATT & $67 \cdot 9$ & $\begin{array}{l}\text { Sequencing primer corresponding to residues } \\
292-311 \text { of } P \text {. vestita rRNA sequence }\end{array}$ \\
\hline 15 & CCCGCCTGCTAAATA & $61 \cdot 4$ & $\begin{array}{l}\text { Sequencing primer corresponding to residues } \\
1325-1339 \text { of } P \text {. vestita rRNA sequence }\end{array}$ \\
\hline 16 & CAGCCGCGGTAATT & $61 \cdot 5$ & $\begin{array}{l}\text { Sequencing primer corresponding to residues } \\
545-558 \text { of } P \text {. vestita rRNA sequence }\end{array}$ \\
\hline 17 & CTTTTTAACTGCAACAAC & $57 \cdot 5$ & $\begin{array}{l}\text { Sequencing primer complementary to residues } \\
583-600 \text { of } P \text {. vestita rRNA sequence }\end{array}$ \\
\hline 18 & CGGGGGGAGTATGGTC & $67 \cdot 2$ & $\begin{array}{l}\text { Sequencing primer corresponding to residues } \\
1097-1112 \text { of } P \text {. vestita rRNA sequence }\end{array}$ \\
\hline
\end{tabular}

* The melting temperature was calculated using oligo version 4.0 software, by the nearest-neighbour method (Breslauer et al., 1986; Schildkraut \& Lifson, 1965).

SET buffer, to prevent evaporation of the hybridization mixture, and incubated in the dark for $12-15 \mathrm{~h}$ at $37-55^{\circ} \mathrm{C}$, the temperature depending on the $T_{\mathrm{m}}$ of the probe (see Table 1). Controls were set up at the same time and treated in the same manner. After incubation the slides were washed three times (10 min each) in fresh, pre-warmed, $0.2 \times$ SET buffer at $45^{\circ} \mathrm{C}$, air-dried and mounted in glycerol/PBS $(9: 1, \mathrm{v} / \mathrm{v})$ antifade solution (Citifluor) for fluorescence microscopy.

A simplified hybridization procedure was devised to prepare bulk samples for flow cytometry. Cells that had been stored in ethanol were pelleted and the supernatant was removed. Fifty microlitres of a pre-warmed $\left(45^{\circ} \mathrm{C}\right.$ for PV, PI2, CON1 and EUK probes) hybridization mixture comprising $5 \times$ SET buffer containing $15 \mathrm{pmol}$ of each of one or more probes was then added to the pelleted cells in the micro-centrifuge tube, and held at $45^{\circ} \mathrm{C}$ in the dark in a waterbath overnight (about $12 \mathrm{~h}$ ). After incubation, $350 \mu \mathrm{l}$ prewarmed PBS ( $\mathrm{pH} 7 \cdot 2$ ) was added and the mixture was incubated for a further $20 \mathrm{~min}$. The cells were then pelleted and the supernatant removed before the cells were resuspended in PBS (typically $50 \mu \mathrm{l}$ ) and analysed by flow cytometry. The same hybridization procedure was used for later microscopical tests of the specificity of probe binding without any obvious loss of quality. About $10 \mu \mathrm{l}$ of the suspension was placed on a clean slide and airdried in the dark before addition of Citifluor and examination by fluorescence microscopy.

Slides were examined using a Leitz Diaplan microscope with a green filter set $(\mathrm{BG} 36+\mathrm{S} 546 / \mathrm{K} 610)$ for TRITC-labelled probes, and a blue filter set (KP490/K510) for FITC-labelled probes. A Bio-Rad MRC 600 Confocal Imaging System, incorporating a Nikon microscope, was also used to compare the fluorescence of specimens stained by hybridization with fluorescently labelled probes, photographs being taken of specimens illuminated by a krypton-argon laser using excitation filters at $488 \mathrm{~nm}$ for FITC- and $568 \mathrm{~nm}$ for TRITClabelled probes.

A reduction in the hybrid stability of probe binding at a given temperature by the inclusion of formamide in the hybridization buffer was reported by Bresser \& Evinger-Hodges (1987) and Bertin et al. (1990). Therefore, tests were performed with various probe combinations in which $0 \%, 10 \%, 20 \%$ or $40 \%$ deionized formamide was incorporated in the hybridization buffer and incubated at $45^{\circ} \mathrm{C}$ for $12 \mathrm{~h}$.

Two to fivefold amplification of the fluorescence signal by use of biotinylated probes in the hybridization stage, with subsequent detection of these probes with fluorescently labelled avidin or streptavidin, has been reported by Lim et al. (1993). In tests of this approach, biotinylated PV1 and CON1 probes were substituted for fluorescent probes in the standard protocol used above, except that following the washing step after incubation with the probe the cells were air-dried, overlaid with $10-20 \mu \mathrm{l}$ of avidin-TRITC conjugate $(20 \mu \mathrm{g}$ $\left.\mathrm{ml}^{-1}\right)$ and incubated at $4{ }^{\circ} \mathrm{C}$ for $15-35 \mathrm{~min}$. The cells were then washed three times in $50 \mathrm{mM}$ Tris/ $\mathrm{HCl}$ buffer $\left(\mathrm{pH} 8.3\right.$ ) at $4{ }^{\circ} \mathrm{C}$ for $15 \mathrm{~min}$ each, before the slides were air-dried and mounted for microscopic analysis. In addition to the controls already mentioned, samples of flagellates were incubated in the hybridization mixture without any probe before exposure to the avidin-TRITC conjugate.

Flow cytometric analysis was carried out using a BectonDickinson FACSort machine using $15 \mathrm{~mW}$ excitation at $488 \mathrm{~nm}$ to detect cells hybridized with FITC-labelled probes. Cell size data were collected from the right angle light scatter channel, and cellular fluorescence data from the green fluorescence channel.

Phylogenetic analysis of $P$. vestita and $P$. foraminifera with 23 other heterokont flagellates was preceded by alignment of sequences using CLUSTAL $w$ (version 1.4) (Thompson et al., 1994). The aligned sequences were compared using PHYLIP (version 3.5c) DNA Distance, Parsimony and Maximum Likelihood programs (Felsenstein, 1995).

\section{RESULTS}

\section{Determination of the SSU rRNA gene sequences, and selection of probe sequences}

Six DNA fragments, with approximate sizes of $0 \cdot 4,0 \cdot 45$, $1.0,1.2,1.4$ and $1.5 \mathrm{~kb}$, were selectively amplified by PCR with different primers from the SSU rRNA gene of 


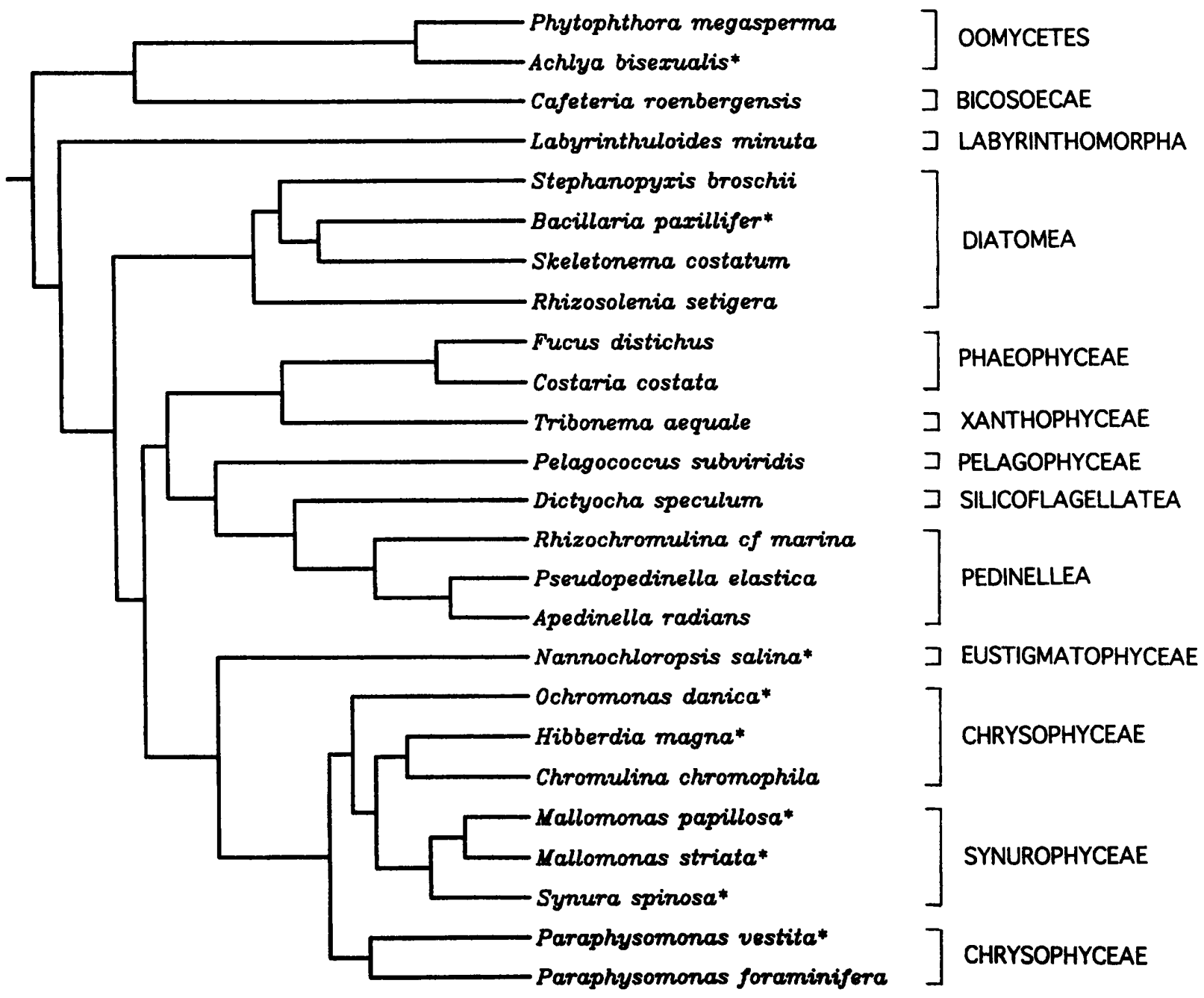

Fig. 2. Phylogenetic analysis of aligned SSU rRNA sequences by the maximum likelihood method with Molecular Clock (version 3.572c of Felsenstein, 1995) to show the relationships of Paraphysomonas species to a selection of other heterokont protists. The same tree was produced by each of 20 replicate analyses, differing in the random order in which sequences were inserted. All sequences used are in the EMBLGenBank databases; those used in probe design are marked with an asterisk.

$P$. vestita. Sequencing of these fragments allowed determination of a sequence of 1745 bp from the SSU rRNA gene of $P$. vestita. Alignment of this sequence with those of closely related organisms suggested that it accounted for approximately $98 \%$ of the SSU rRNA of this nanoflagellate. A sequence of $1686 \mathrm{bp}$ was determined for P. foraminifera, representing $95 \%$ of the SSU rRNA of this species, and sequences of the V4 region and flanking conserved sections comprising a 328 bp length for $P$. butcheri and a 325 bp length for $P$. imperforata were also determined.

A phylogenetic tree comparing the SSU rRNA gene sequences of $P$. vestita and $P$. foraminifera with sequences from 23 other heterokont species, including related members of the Chrysophyceae, is shown in Fig. 2. While use of both the maximum likelihood and parsimony methods of tree construction gave similar tree topology, the DNA Distance method placed O. danica between $P$. vestita and $P$. foraminifera. Comparison of partial sequences (V4 region only) of four Paraphysomonas species with the $O$. danica sequence (Table 2) showed that $P$. butcheri and $P$. imperforata are quite close to $P$. foraminifera ( $>90 \%$ similarity), whilst these three Paraphysomonas species showed a little more similarity to $O$. danica than to $P$. vestita in this region.

Eight 'variable' regions, V1-V5 and V7-V9, of the eukaryoteSSU rRNA sequence are commonly recognized (Neefs et al., 1990), and these contained most of the base positions which were different between $P$. vestita and $P$. foraminifera, and the most closely related organisms with which they were compared (Fig. 2). Differences between these sequences were most frequent in the hypervariable V4 domain (Nickrent \& Sargent, 1991). Thus, three probes (PV1, PV4 and PV5, Table 1) were designed to target sequences in the V4 domain of $P$. vestita. In addition, PV2 was targeted at a sequence in 
Table 2. Pairwise comparisons showing the percentage nucleotide sequence similarity between the V4 domain from the SSU rRNA genes of four Paraphysomonas species and O. danica.

The number of bases in the equivalent length and the $A+T$ content of this length (positions 619-842 in the P. vestita sequence) of the SSU rRNA genes of the five flagellates is also shown.

\begin{tabular}{|lcccccc|}
\hline & $\begin{array}{c}\text { Length } \\
\text { (bases) }\end{array}$ & $\begin{array}{c}\text { A+T } \\
\text { content } \\
\text { (mol\%) }\end{array}$ & P. vestita & P. butcheri & P. foraminifera & P. imperforata \\
\hline P. vestita & 223 & 74 & - & - & - & \\
P. butcheri & 210 & 47 & $62 \cdot 0$ & - & - & - \\
P. foraminifera & 210 & 50 & $65 \cdot 7$ & $90 \cdot 0$ & - & - \\
P. imperforata & 210 & 47 & $63 \cdot 9$ & $93 \cdot 8$ & $96 \cdot 2$ & - \\
O. danica & 208 & 55 & $62 \cdot 3$ & 74.8 & $74 \cdot 3$ & $75 \cdot 2$ \\
\hline
\end{tabular}

the V2 domain (near the $5^{\prime}$ end) and PV3 was targeted at the V9 domain ( $3^{\prime}$ end) (Table 1 ).

\section{Tests of protocols for hybridization}

Fixation. Nanoflagellate cells are fragile and their use in quantitative hybridization studies imposed three requirements of fixation: there should be no lysis of the flagellate cells, minimal cell shrinkage and no autofluorescence due to the fixative. Comparative tests with fixatives gave the following results. Cells fixed with $2 \%$ formaldehyde, which is commonly used in hybridization studies because it causes no autofluorescence, were reduced in numbers by $39 \%$ through lysis, and the flagellate cells shrank in volume to $31 \%$ of their former size. Glutaraldehyde $(0.5 \%)$ caused little lysis, but the cells shrank to only $48 \%$ of their former volume and were strongly autofluorescent. Flagellates were also moderately autofluorescent after fixation with $1 \%$ acetic acid, in which $22 \%$ of cells lysed and the survivors were $51 \%$ smaller in volume than the live cells. Mercuric chloride caused no lysis, minimal shrinkage $(16 \%$ by volume) and very little autofluorescence. At a later stage TCA was identified as a good fixative; cells fixed in $0.4 \%$ TCA showed low levels of autofluorescence and only modest shrinkage $(<20 \%)$, with little lysis. The cells became sticky after fixation in TCA, and tended to clump; there was also some loss in cell numbers by adhesion to the walls of storage vessels, so fixed cells were immediately transferred to $95 \%$ ethanol. Mercuric chloride and TCA were selected as the best fixatives, with TCA being preferred for most purposes since it is less hazardous. $P$. vestita fluoresced more brightly and the bacterial fluorescence was less in samples hybridized with specific and universal probes after fixation with TCA than in samples fixed with mercuric chloride. The binding of control probes by TCA-fixed cells was similar to that by mercuric-chloride-fixed cells, so the difference between hybridization of specific and control probes was more marked after TCA fixation.

Increasing stringency of binding. $P$. vestita fixed with mercuric chloride bound all five PV probes, imparting a bright fluorescence; the probes also made bacteria just visible by epifluorescence microscopy. Both flagellates and bacteria showed dim fluorescence with control probes. Differences in fluorescence with these probes were used to test methods of increasing the stringency of hybridization. Comparisons of the fluorescence of $P$. vestita with non-specific 'background' fluorescence, and comparisons of the fluorescence of $P$. vestita produced by PV probes with that produced by CON probes, were used to judge by eye which protocol gave the highest contrast with PV probes.

Inclusion of BSA in the hybridization buffer reduced the non-specific labelling without affecting binding of the PV probes. Formamide reduced fluorescence with PV probes, but not with CON probes; with formamide at $20 \%$ or more the fluorescence with PV and CON probes was indistinguishable.

Biotinylated probes. All samples which were incubated with the avidin-TRITC conjugate fluoresced strongly, irrespective of the type of probe present in the hybridization mixture, and even if no probe at all was present in the mixture. Non-specific staining of $V$. natriegens and background staining of debris on the slide were also high in each sample. Attempts to reduce non-specific labelling by the following methods were all unsuccessful: varying the duration of hybridization $(3-15 \mathrm{~h})$; increasing the number of post-hybridization washes from 3 to 6 , and including $0.05 \%$ Tween 20 and $2 \%$ BSA in the wash buffer; pretreating the cells before avidin-TRITC labelling with $0.05 \mathrm{M}$ Tris $/ \mathrm{HCl}$ buffer containing $0.05 \%$ Tween 20 and $2 \%$ BSA for $1 \mathrm{~h}$; placing the slide receptacles on a rocker during all washing stages; and varying the amount of avidin-TRITC conjugate that was used $\left(10-20 \mu \mathrm{l}\right.$ at $\left.20 \mu \mathrm{g} \mathrm{ml}^{-1}\right)$ and the duration of application (10-35 $\mathrm{min})$.

\section{Specificity of binding of probes to cells of different types}

Each of the five species-specific probes, PV1-PV5, hybridized to $P$. vestita cells when used singly. Probes labelled with TRITC were made first and most earlier 


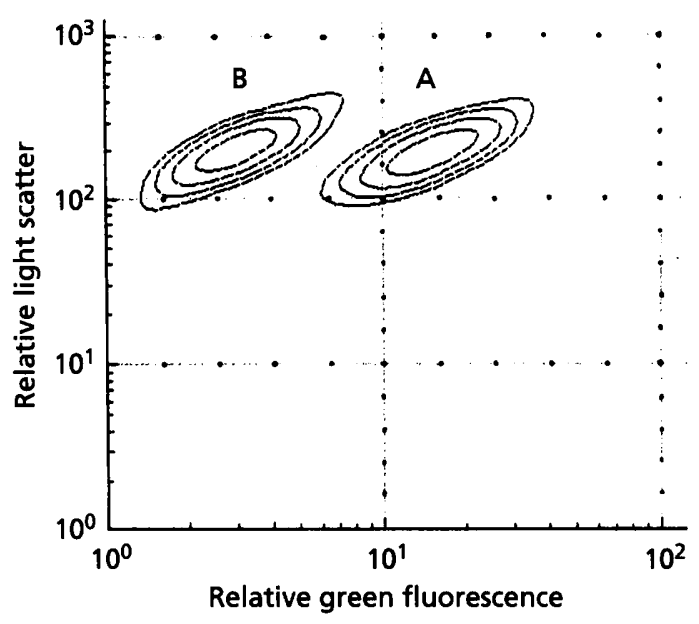

Fig. 3. Flow cytometry of samples of $P$. vestita cells hybridized with (A) the PV1 probe, or (B) the PI2 probe (effectively a control probe). Over 7000 cells of each sample were analysed and contour plots of the numbers of FITC-labelled cells, peaking at the centre of each population, are shown superimposed on the same axes which indicate cell size (light scatter) and relative green fluorescence. The size of cells in each population is the same, but the fluorescence is quite different; the mean fluorescence value (in arbitrary units) for the population hybridized with PV1 was 14.8 , while that for the PI2 probe was $\mathbf{2 \cdot 8}$.

tests were made with them. To facilitate comparisons of fluorescence with these labels, during tests using flagellate cells fixed with mercuric chloride, fluorescence intensity was increased by using probes in pairs; namely, PV1 and PV4, PV2 and PV5, PV1 and PV3, CON1 and CON2, and UNIA and UNIC. When cells fixed with TCA were used later it was found that the fluorescence using TRITC- or FITC-labelled probes was brighter and individual probes (namely PV1, PV4, EUK, CON1 and PI2) could be used alone. Background debris or $V$. natriegens showed very low fluorescence with PV probes. The universal probes (UNI) stained both $P$. vestita and $V$. natriegens, while the eukaryote probe (EUK) stained flagellates and not bacteria. Control probes $(\mathrm{CON})$ imparted a dim background fluorescence to all types of cell, but this was less than that produced by any of the taxonomically relevant species- or groupspecific probes. The difference between the intensity of fluorescence of $P$. vestita hybridized with the same quantity of PV1 and PI2 probes was confirmed by flow cytometry (Fig. 3). PI2 imparted less fluorescence than CON probes to any of the cells used, including (unaccountably) P. imperforata.

When cells of $P$. vestita (about $7 \mu \mathrm{m}$ diameter) were mixed with cells of $P$. butcheri, $P$. foraminifera and $P$. imperforata (each about $4 \mu \mathrm{m}$ diameter) and then used in hybridization studies, the staining properties of $P$. vestita cells could be compared with those of the other species, while they could be clearly distinguished by their size. The species-specific PV probes stained only the larger $P$. vestita cells, whereas the EUK probe stained all flagellate cells (Fig. 4a). In a similar experiment with a mixture of protozoa that were more taxonomically diverse, PV probes only hybridized with $P$. vestita, while the EUK probe hybridized with the ciliate $U$. marinum and the flagellates $B$. saliens, $C$. roenbergensis and $P t$. danica as well as with $P$. vestita (Fig. 4 b).

\section{DISCUSSION}

The nanoflagellate $P$. vestita could be grown in large enough numbers in the absence of any other eukaryote cells for direct sequencing of the SSU rRNA gene to be performed without preliminary cloning in a plasmid. Sequence comparisons placed the genus Paraphysomonas firmly within the Chrysophyceae, where it had been assigned on the basis of morphological characters. The SSU rRNA gene of $P$. vestita showed numerous sequence differences from three other Paraphysomonas species (which are morphologically closely similar to one another), so it was fortunate that this species had been selected for probe development. The high proportion of $\mathrm{A}+\mathrm{T}$ bases in the $P$. vestita sequence (Table 2) may explain why different phylogenetic analyses place this species in different positions. Although there was some doubt about accessibility of different parts of the SSU rRNA for hybridization with oligonucleotide probes, all five of the selected target sequences proved accessible and hybridization of all PV probes was essentially similar. When two probes were designed using data from a partial (V4) sequence of $P$. imperforata SSU rRNA neither hybridized with this flagellate, although EUK and UNI probes did hybridize successfully.

Mercuric chloride was initially the preferred fixative for in vitro hybridization, but TCA was later seen to give a higher difference in fluorescence intensity between PV and CON probes than mercuric chloride. It is thought that fixation by mercuric chloride could limit hybridization for one or more reasons: it may reduce accessibility to binding sites by the probe because it enhances crosslinking between nucleic acid strands (Katz, 1963); or the binding of mercury ions may affect the melting temperature of nucleic acid hybrids (Dale \& Ward, 1975).

Components of the hybridization buffer also influence the efficiency of hybrid formation. The presence of BSA was shown to maximise the difference between labelling with specific probes and non-specific labelling, although it slightly reduced the level of specific labelling. By contrast, the presence of formamide, which is routinely incorporated in hybridization buffers because it has been found to reduce hybrid stability at a given temperature when using longer nucleic acid probes (e.g. Trebesius et al., 1994), did not increase the difference between specific and non-specific labelling since it reduced the intensity of binding of both specific and control probes.

Our results show that $P$. vestita-specific oligonucleotide probes may be used for the identification of species of nanoflagellates in samples containing mixtures of micro- 
(a)

(i)
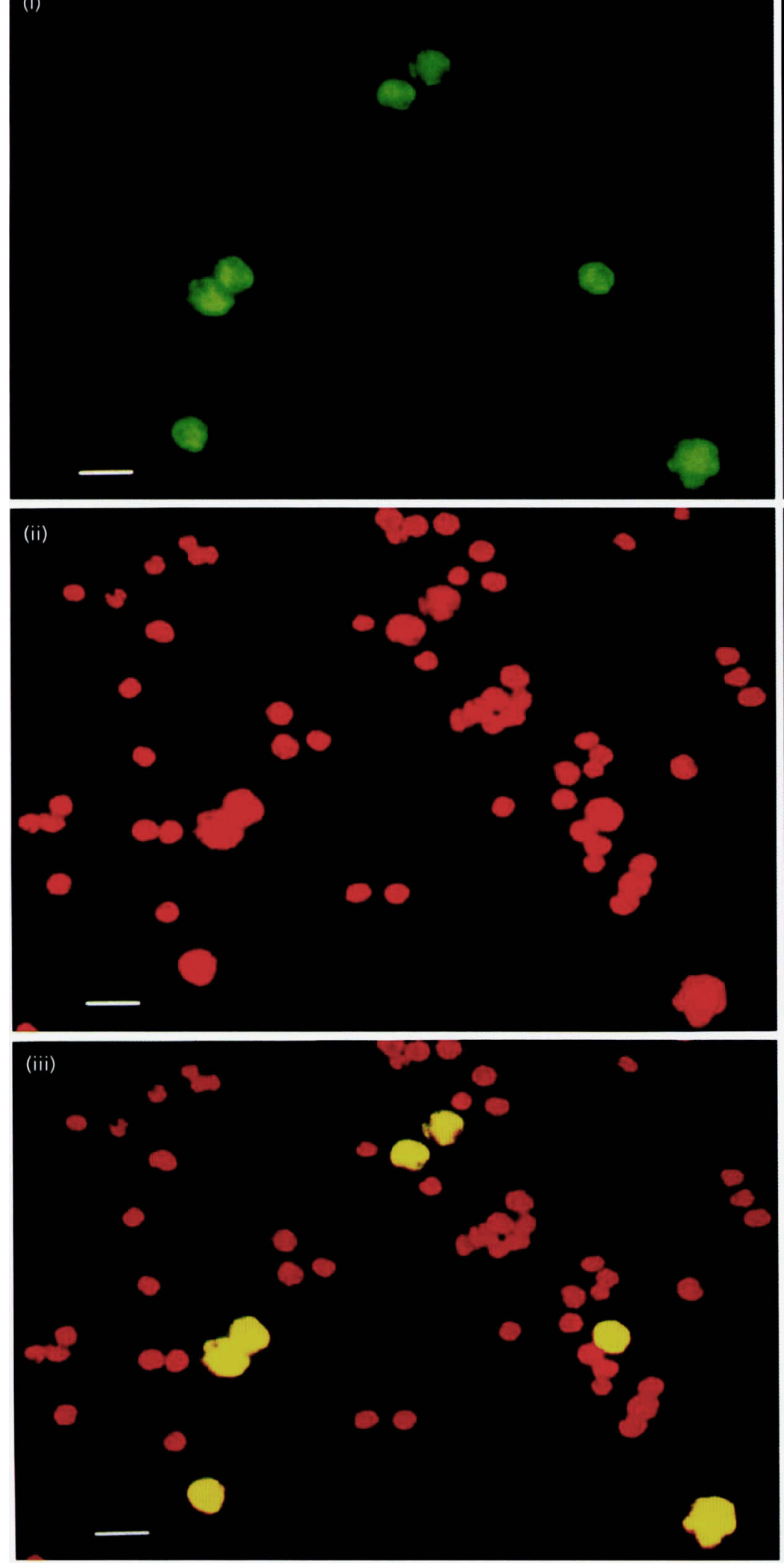

(b)
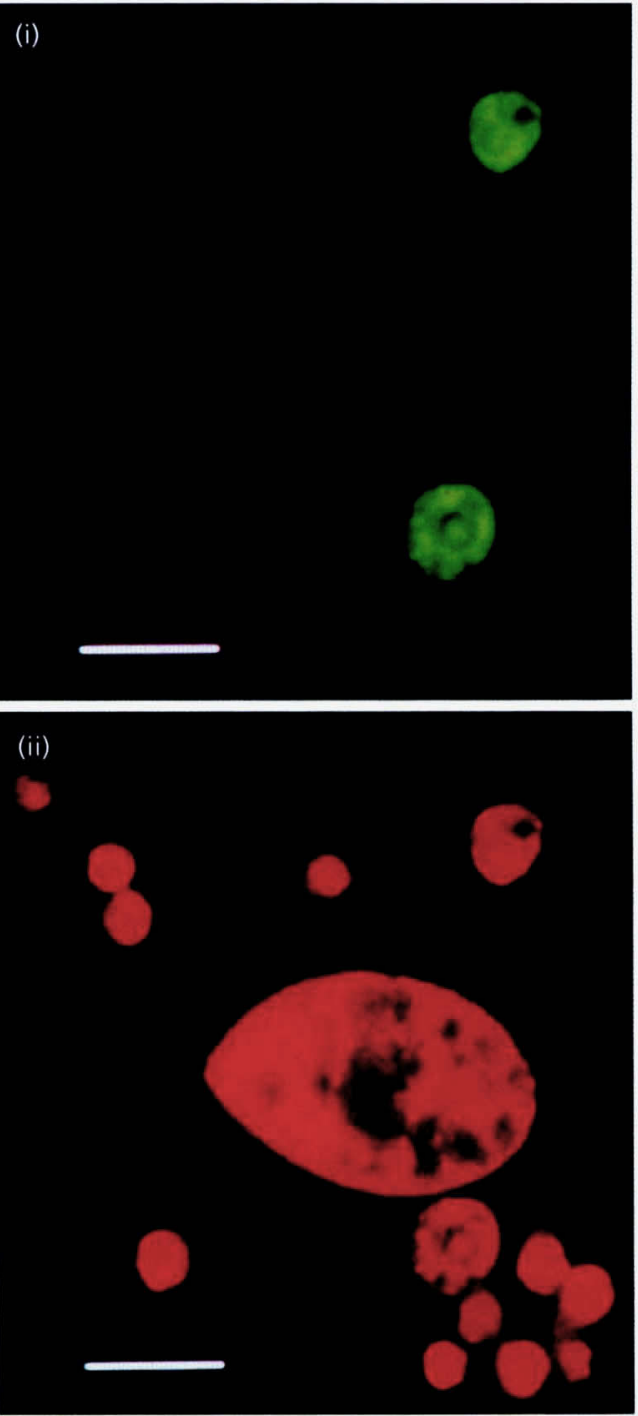

(iii)

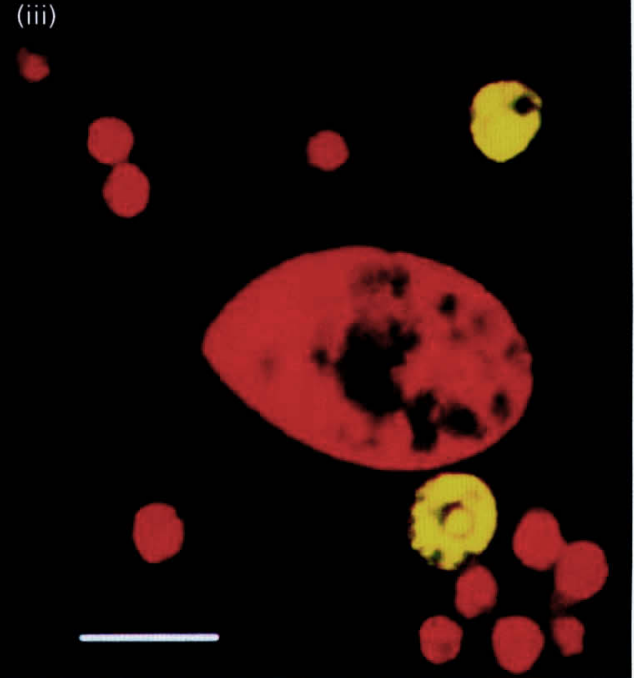

Fig. 4. Micrographs of (a) a mixture of four Paraphysomonas species and (b) a wider mixture of four flagellate and one ciliate species after hybridization with a mixture of PV1 and EUK probes. Samples were illuminated (i) at $488 \mathrm{~nm}$ to locate FITC-labelled PV1, (ii) at $568 \mathrm{~nm}$ to show TRITC-labelled EUK and (iii) at 488 and $568 \mathrm{~nm}$ showing PV1and EUK (see text). Confocal microscopy with $\times 60$ objective. Bars, $10 \mu \mathrm{m}$. 
organisms. They illustrate the potential of these probes for use in ecological studies where the specific binding of species-specific or group-specific probes could be used to quantify the relative contribution of different taxa to nanoplankton populations. The ability to determine the proportion of specific types of flagellates in mixtures of protists where species are difficult to separate will be valuable, for example, in assessment of toxic bloom populations or in experimental studies of growth or predation, both in field samples and in the laboratory. This can be achieved by epifluorescence microscopy, substituting specific probes for normal fluorescent dyes in the standard techniques for counting and estimating the biomass of stained cells on black filters (Burkill et al., 1994). Counts of stained cells can also be made by flow cytometry, as illustrated in Fig. 3.

\section{ACKNOWLEDGEMENTS}

This research was supported by NERC grant GST/02/571, and was a component of the 'GAMES' Special Topic research programme. We would like to thank Dr Sue Tong for providing pure cultures of flagellates which she had isolated and electron micrographs of their scales, Dr Paul Kemp for giving J.R. hospitality and advice on hybridization procedures, Dr Steve Jane for assistance with confocal microscopy and Dr Glen Tarran for assistance with flow cytometry.

\section{REFERENCES}

Amann, R. I., Krumholz, L. \& Stahl, D. A. (1990). Fluorescent oligonucleotide probing of whole cells for determinative, phylogenetic and environmental studies in microbiology. $J$ Bacteriol $172,762-770$.

Amann, R. I., Ludwig, W. \& Schleifer, K.-H. (1992). Identification and in situ detection of individual bacterial cells. FEMS Microbiol Lett 100, 45-50.

Amann, R. I., Ludwig, W. \& Schleifer, K.-H. (1995). Phylogenetic identification and in situ detection of individual microbial cells without cultivation. Microbiol Rev 59, 143-169.

Azam, F., Fenchel, T., Field, J. G., Meyer-Reil, L. A. \& Thingstad, F. (1983). The ecological role of water column microbes in the sea. Mar Ecol Prog Ser 10, 257-263.

Bertin, B., Broux, O. \& Van Hoegaerden, M. (1990). Flow cytometric detection of yeast by in situ hybridisation with a fluorescent ribosomal RNA probe. J Microbiol Methods 12, 1-12.

Bohlool, B. B. \& Schmidt, E. L. (1980). The immunofluorescence approach in microbial ecology. Adv Microb Ecol 4, 203-241.

Breslauer, K. J., Frank, R., Blocker, H. \& Markey, L. A. (1986). Predicting DNA duplex stability from the base sequence. Proc Natl Acad Sci USA 83, 3746-3750.

Bresser, J. \& Evinger-Hodges, M. (1987). Comparison and optimisation of in situ hybridisation procedures yielding rapid, sensitive mRNA detections. Gene Anal Tech 4, 89-104.

Burkill, P. H., Edwards, E. S., Landry, M., Paranjape, M., Reckermann, M., Sieracki, M., Sleigh, M. A., Stoecker, D. K. \& Verity, P. (1994). Microzooplankton biomass: JGOFS protocols. In Protocols for the Joint Global Ocean Flux Study (JGOFS) Core Measurements, Intergovernmental Oceanographic Commission Manual and Guide, vol. 29, pp.147-151. Edited by A. H. Knap. Paris: UNESCO.
Campbell, L., Shapiro, L. P. \& Haugen, E. (1994). Immunochemical characterization of eukaryotic ultraplankton from the Atlantic and Pacific oceans. J Plankton Res 16, 35-51.

Clarholm, M. (1984). Microbes as predators or prey. Heterotrophic, free-living protozoa: neglected microorganisms with an important task in regulating bacterial populations. In Current Perspectives in Microbial Ecology, pp. 321-326. Edited by M. J. Klug \& C. A. Reddy. Washington, DC: American Society for Microbiology.

Dale, R. M. K. \& Ward, D. C. (1975). Mercurated polynucleotides: new probes for hybridisation and selective polymer fractionation. Biochemistry 14, 2458-2469.

DeLong, E. F., Wickam, G. S. \& Pace, N. R. (1989). Phylogenetic stains: ribosomal RNA-based probes for the identification of single cells. Science 243, 1360-1363.

DeLong, E. F., Wu, K. Y., Prézelin, B. B. \& Jovine, R. V. M. (1994). High abundance of Archaea in Antarctic marine picoplankton. Nature 371, 695-697.

Devereux, R., Kane, M. D., Winfrey, J. \& Stahl, D. A. (1992). Genus- and group-specific hybridisation probes for determination and environmental studies of sulphate reducing bacteria. Syst Appl Microbiol 15, 601-609.

Felsenstein, J. (1995). Phylip Manual (version 3.5c). Seattle: University of Washington.

Fenchel, T. (1982). Ecology of heterotrophic microflagellates. IV. Quantitative occurrence and importance as bacterial consumers. Mar Ecol Prog Ser 9, 35-42.

Fenchel, T. (1988). Marine plankton food chains. Annu Rev Ecol Syst 19, 19-38.

Giovannoni, S. J., De Long, E. F., Olsen, G. J. \& Pace, N. R. (1988). Phylogenetic group-specific oligodeoxynucleotide probes for the identification of single microbial cells. J Bacteriol 170, 720-726.

Giovannoni, S. J., Britschgi, T. B., Moyer, C. L. \& Field, K. G. (1990). Genetic diversity in Sargasso Sea bacterioplankton. Nature 345, 60-63.

Göbel, U. B., Geiser, A. \& Stanbridge, E. J. (1987). Oligonucleotide probes complementary to variable regions of ribosomal RNA discriminate between Mycoplasma species. J Gen Microbiol 133, 1969-1974.

Hicks, R. E., Amann, R. I. \& Stahl, D. A. (1992). Dual staining of natural bacterioplankton with 4',6-diamidino-2-phenylindole and fluorescent oligonucleotide probes targeting Kingdom-level $16 \mathrm{~S}$ rRNA sequences. Appl Environ Microbiol 58, 2158-2163.

Katz, S. (1963). The reversible reaction of $\mathrm{Hg}(\mathrm{II})$ and doublestranded polynucleotides. A step function theory and its significance. Biochim Biophys Acta 68, 240-253.

Lee, S. \& Kemp, P. F. (1994). Single-cell RNA content of natural marine planktonic bacteria measured by hybridization with multiple 16S rRNA-targeted fluorescent probes. Limnol Oceanogr 39, 869-879.

Lee, S., Malone, C. \& Kemp, P. F. (1993). Use of multiple 16S rRNA-targeted fluorescent probes to increase signal strength and measure cellular RNA from natural planktonic bacteria. Mar Ecol Prog Ser 101, 193-201.

Lim, E. L., Amaral, L. A., Caron, D. A. \& Delong, E. F. (1993). Application of rRNA-based probes for observing marine nanoplanktonic protists. Appl Environ Microbiol 59, 1647-1655.

Lim, E. L., Caron, D. A. \& DeLong, E. F. (1996). Development and field application of a quantitative method for examining natural assemblages of protists with oligonucleotide probes. Appl Environ Microbiol 62, 1416-1423. 
Manz, W., Szewzyk, U., Ericsson, P., Amann, R., Schleifer, K.-H. \& Stenstrom, T.-A. (1993). In situ identification of bacteria in drinking water and adjoining biofilms by hybridisation with $16 \mathrm{~S}$ and $23 \mathrm{~S}$ rRNA-directed fluorescent oligonucleotide probes. Appl Environ Microbiol 59, 2293-2298.

Neefs, J.-M., Van de Peer, Y., Hendricks, L. \& De Wachter, R. (1990). Compilation of small ribosomal subunit RNA sequences. Nucleic Acids Res 18 (suppl.), 2237-2317.

Neefs, J.-M., Van de Peer, Y., De Rijk, P., Goris, A. \& De Wachter, R. (1991). Compilation of small ribosomal subunit RNA sequences. Nucleic Acids Res 19 (suppl.), 1987-2018.

Nickrent, D. L. \& Sargent, M. L. (1991). An overview of the secondary structure of the V4 region of Eukaryotic small-subunit ribosomal RNA. Nucleic Acids Res 19, 227-235.

Olsen, G. J. (1994). Archaea, Archaea, everywhere. Nature 371, 657-658.

Schildkraut, C. \& Lifson, S. (1965). Dependence of the melting temperature of DNA on salt concentration. Biopolymers 3, 195-208.

Sherr, E. B. \& Sherr, B. F. (1994). Bacterivory and herbivory: key roles of phagotrophic protists in pelagic food webs. Microb Ecol 28, 223-235.
Stahl, D. A. \& Amann, R. (1991). Development and application of nucleic acid probes. In Nucleic Acid Techniques in Bacterial Systematics, pp. 205-244. Edited by E. Stackebrandt \& M. Goodfellow. Chichester: Wiley.

Stahl, D. A., Flesher, B., Mansfield, H. R. \& Montgomery, L. (1988). Use of phylogenetically based hybridisation probes for studies of ruminal microbial ecology. Appl Environ Microbiol 54, 1079-1084.

Thompson, J. D., Higgins, D. G. \& Gibson, T. J. (1994). Clustal W : improving the sensitivity of progressive multiple sequence alignment through sequence weighting, position-specific gap penalties and weight matrix choice. Nucleic Acids Res 22, 4673-4680.

Trebesius, K., Amann, R., Ludwig, W., Muhlegger, K. \& Schleifer, K.-H. (1994). Identification of whole fixed bacterial cells with nonradioactive $23 \mathrm{~S}$ rRNA-targeted polynucleotide probes. Appl Environ Microbiol 60, 3228-3235.

Ward, D. M., Weller, R. \& Bateson, M. M. (1990). 16S rRNA sequences reveal numerous uncultured microorganisms in a natural community. Nature 345, 63-65.

Received 17 July 1996; revised 19 November 1996; accepted 13 January 1997. 